\title{
ANALISIS KARAKTERISTIK INDIVIDU DENGAN KELUHAN KELELAHAN KERJA PADA PENGEMUDI TAKSI DI RUNGKUT SURABAYA
}

\author{
Tika Nanda Prastuti*, Tri Martiana** \\ ****Departemen Keselamatan dan Kesehatan Kerja, Fakultas Kesehatan Masyarakat \\ Universitas Airlangga, Surabaya, Jawa Timur, Indonesia \\ Alamat Korespondensi: \\ Tika Nanda Prastuti \\ Email: tikananda.1992@gmail.com
}

\begin{abstract}
Each type of work will cause fatigue. Fatigue is decreasing a person's condition so that no longer able to perform the work or activities. This study is to find out the relationship between individual characteristics such as age, work period, smoking habits, exercise habits, nutritional status with work fatigue complaints of taxi driver. The method used in this research was observational analytic with cross sectional approach. This study uses a questionnaire tools work fatigue Industrial Fatigue Research Committee (IFRC), weight scales and height or microtoise Stature Meter. The population in this study was a taxi driver in Rungkut Surabaya who work at night time from $14.00 \mathrm{pm}-12.00 \mathrm{pm}$. The study sample of 50 drivers by used purposive sampling method. The results of this study used Chi-Square. Statistical test results indicate that the age of the driver has a low relationship strength, the driver's working period has a very strong relationship strength, smoking habits driver has a very low relationship strength, exercise habits and nutritional status drivers has a strong relationship. The conclusion that can be drawn from the results of the study there was no association between age, work period, smoking, exercise habits, and nutritional status and work fatigue complaints of taxi drivers. Therefore, need for socialization or briefing about the dangers of smoking to health, eating vitamin partially substitute for cigarettes and a healthy lifestyle.
\end{abstract}

Keywords: work period, nutritional status, exercise habits, indivudual characteristics, work fatigue complaints, taxi drivers

\begin{abstract}
ABSTRAK
Setiap jenis pekerjaan akan menimbulkan kelelahan kerja. Kelelahan yaitu menurunnya kondisi seseorang sehingga tidak sanggup lagi melakukan pekerjaan atau kegiatan. Penelitian ini dilakukan dengan tujuan mengetahui hubungan antara karakteristik individu meliputi umur, masa kerja, kebiasaan merokok, kebiasaan olahraga, status gizi dengan keluhan kelelahan kerja pada pengemudi taksi. Penelitian ini menggunakan metode observasional analitik dengan pendekatan cross sectional. Alat ukur penelitian berupa lembar kuesioner keluhan kelelahan kerja subjektif dari Industrial Fatique Research Committee (IFRC), timbangan berat badan dan tinggi badan atau Microtoise Stature Meter. Populasi pada penelitian ini adalah pengemudi taksi di Rungkut Surabaya yang waktu kerja pada malam hari mulai pukul 14.00 siang-12.00 siang. Sampel berjumlah 50 orang pengemudi dengan metode purposive sampling. Hasil penelitian menggunakan uji Chi-Square. Hasil uji statistik menunjukkan bahwa umur pengemudi memiliki kekuatan hubungan rendah, masa kerja pengemudi memiliki kekuatan hubungan sangat kuat, kebiasaan merokok pengemudi memiliki kekuatan hubungan sangat rendah, kebiasaan olahraga dan status gizi pengemudi memiliki kekuatan hubungan kuat. Kesimpulan yang dapat ditarik dari hasil penelitian adalah tidak terdapat hubungan antara kebiasaan merokok, masa kerja, umur, kebiasaan olahraga, dan status gizi dengan keluhan kelelahan kerja pada pengemudi taksi. Oleh karena itu, perlu adanya sosialisasi atau briefing tentang bahaya dari merokok bagi kesehatan pengemudi, mengonsumsi vitamin sebagai pengganti rokok dan pola hidup sehat.
\end{abstract}


Kata kunci: masa kerja, status gizi, kebiasaan olahraga, karakteristik individu, keluhan kelelahan kerja, pengemudi taksi

\section{PENDAHULUAN}

Negara berkembang memiliki perkembangan jasa di sektor transportasi laut, darat, dan udara sangat pesat. Bangsa indonesia sebagai bangsa yang memiliki sarana transportasi yang cukup baik saat ini berusaha untuk meningkatkan dan memajukan pelayanan jasa transportasi. Perkembangan jasa transportasi di Indonesia diikuti oleh jasa angkutan darat salah satunya menyangkut angkutan umum. Taksi adalah salah satu contoh jasa angkutan umum.

Transportasi didefinisikan sebagai pemindahan barang dan manusia dari tempat asal ke tempat tujuan. Di Asia Tenggara pada tahun 2010 kecelakaan lalu lintas menimbulkan korban tewas sebanyak 33.815 jiwa dengan rata-rata 18,5 korban jiwa per 100.000 populasi. (WHO, 2013)

Di Indonesia penyebab utama terjadinya kecelakaan lalu lintas karena meningkatnya jumlah kendaraan setiap tahunnya dan faktor kelalaian manusia. Berdasarkan data Kepolisian RI pada tahun 2012 terjadi 109.038 kasus kecelakaan lalu lintas dengan korban jiwa sebanyak 27.441 orang, dengan potensi kerugian sosial ekonomi sekitar Rp 203 triliun - Rp 217 triliun per tahun, kemudian pada tahun 2014 terjadi 95.906 kecelakaan di jalan dengan jumlah meninggal 28.897 jiwa, luka - luka 136.581 jiwa. Dari data tersebut menunjukkan bahwa, pada tahun 2012 sampai tahun 2014 kecelakaan lalu lintas di jalan mengalami penurunan. (Kementerian Perhubungan RI, 2015).

Pada tahun 2012 tercatat 29.730 kecelakaan di Jawa Timur. Dari data tersebut didapatkan jumlah korban jiwa sebanyak 5.840 jiwa. Sementara, jumlah meninggal mencapai 27.441 jiwa.

Penyebab kecelakaan tersebut $80 \%$ karena faktor human eror, selanjutnya karena faktor kendaraan, infrastruktur jalan, faktor cuaca dan lain-lain. Kecelakaan lalu lintas sebagian besar (70\%) adalah kendaraan roda dua, dan selebihnya mobil dan kendaraan besar lainnya (Dewan Perwakilan Rakyat Daerah Provinsi Jawa Timur, 2013).

Kemacetan lalu lintas di kota Surabaya bisa mengakibatkan kelelahan kerja. Berdasarkan survei yang di rilis Castrol Magnatec Stop-Start Index, Surabaya merupakan urutan ke empat paling buruk di dunia pada tahun 2015. Berdasarkan data pertumbuhan kendaraan bermotor di Surabaya tercatat setiap bulan terjadi penambahan 14.000 sepeda motor baru dan mobil mencapai 400 setiap bulan. Volume lalu lintas pada jam puncak seringkali melebihi kapasitas jalan sehingga menimbulkan kemacetan lalu lintas yang berdampak bagi para pengguna jalan. Kemacetan ini membuat waktu tempuh perjalanan kendaraan dari suatu tempat/titik yang lainnya menjadi tidak menentu (Kepolisian Negara RI, 2015).

Menurut Undang-undang No. 22 Tahun 2009 Tentang Lalu Lintas dan Angkutan Jalan mengatakan bahwa pengemudi wajib mengemudikan kendaraannya dengan wajar dan penuh konsentrasi. Hal ini karena pengemudi bertanggung jawab sepenuhnya terhadap keselamatan dirinya, penumpang, muatan yang dibawa maupun pengguna jalan yang lain. Kondisi saat mengemudi menjadi sangat melelahkan bagi anggota tubuh terutama mata dan pikiran karena harus tetap fokus dalam waktu berjam-jam (Kristanto, 2013)

Kelelahan merupakan salah satu faktor yang memengaruhi kecelakaan lalu lintas. Beban kerja yang berlebihan dapat mengakibatkan kelelahan kerja sehinga dapat membuat konsentrasi kerja menurun.

Menurut Aksoro dan Galuh (2009), untuk memulihkan energi ke dalam bentuk semula perlu untuk merubah kebiasaan yang kurang sehat dengan pola hidup sehat. Pola hidup sehat ini bisa dimulai dengan tidur secara teratur, rutin berolahraga, 
mengonsumsi makanan bergizi setiap hari sesuai dengan kebutuhan tubuh masingmasing, tidak mengonsumsi minuman beralkohol dan tidak merokok.

Pekerjaan mengemudi adalah suatu pekerjaan yang memerlukan konsentrasi tinggi karena membutuhkan perpaduan yang tepat dan cepat antara otak, tangan, kaki, dan mata, sehingga mengemudi merupakan pekerjaan yang memiliki risiko tinggi mengalami kelelahan kerja dan berbagai gangguan kesehatan lainnya (Yogisutanti $\mathrm{dkk}, 2013)$.

Lelah diartikan sebagai keadaan fisik dan mental yang berakibat pada menurunnya daya kerja, dan berkurangnya ketahanan tubuh seseorang saat bekerja (Suma'mur, 2009). Faktor-faktor yang dapat menyebabkan kelelahan kerja meliputi: kesegaran jasmani, kebiasaan merokok, masalah psikologis, status kesehatan, jenis kelamin, status kesehatan, waktu kerja, beban kerja, usia dan masalah lingkungan kerja (Tarwaka $\mathrm{dkk}, 2004)$

Karakteristik individu yang berbedabeda setiap pengemudi memungkinkan terjadinya gangguan kesehatan seperti keluhan muskuloskeletal dan kelelahan dengan tingkat berat. (Namira dan Nurhayati, 2014 dalam Fahmi, 2015).

Umyati dkk (2015), mengatakan bahwa jam kerja berlebih maka akan mengakibatkan fisik menjadi lemah. Apabila kualitas tidur buruk maka akan menyebabkan kebutuhan akan tidur tidak mencukupi. Hal ini berdampak pada performa mengemudi dan bisa menyebabkan pengemudi lebih mudah lelah dan menimbulkan rasa ngantuk.

Berdasarkan beberapa penelitian, kelelahan dapat menurunkan produktivitas dan memengaruhi kesehatan pada tenaga kerja. Dilaporkan lebih dari $60 \%$ pekerja yang datang berobat ke poliklinik perusahaan mengalami kelelahan kerja dan perasaan kelelahan kerja merupakan gejala yang paling sering terjadi dengan urutan ke tujuh yang ditemukan pada suatu studi epidemiologi di USA (Setyawati, 2010).
Penelitian ini dilakukan kepada pengemudi taksi Blue Bird di Surabaya. Dahulu Taksi Blue Bird ini dikenal dengan nama Chandra Taksi (CT). Chandra taksi merupakan sebuah usaha keluarga yang menyewakan mobil pribadi secara khusus. Waktu kerja pengemudi taksi Blue Bird rata-rata perhari lebih dari 8 jam. Jam kerja di bagi menjadi dua yaitu pada siang hari mulai pukul 03.00 pagi-24.00 malam atau 21 jam perhari disebut dengan tim pagi dan malam hari mulai pukul 14.00 siang12.00 siang atau 22 jam disebut dengan pengemudi tim malam. Berdasarkan data yang diperoleh ditemukan bahwa kecelakaan kerja pada pengemudi taksi sering terjadi antara pukul 11.00-17.00. Lokasi kejadian kecelakaan ini banyak terjadi di perempatan jalan. Tabrakan terjadi karena pengemudi mengalami kelelahan dan tetap memaksakan diri untuk bekerja. Penelitian ini bertujuan untuk mengetahui analisis karakteristik individu dengan keluhan kelelahan kerja pada pengemudi taksi di Rungkut Surabaya.

\section{METODE PENELITIAN}

Penelitian ini merupakan observasional analitik dengan desain cross sectional. Variabel independent meliputi umur, masa kerja, kebiasaan merokok, kebiasaan olahraga, status gizi, sedangkan variabel dependent dalam penelitian ini adalah kelelahan kerja. Lokasi penelitian adalah di Pool Rungkut Surabaya. Waktu penelitian dilakukan pada bulan Oktober hingga Januari 2017. Subjek yang diteliti dalam penelitian ini adalah pengemudi taksi di Pool Rungkut yang berjumlah 50 orang yang waktu kerjanya pada malam hari mulai pukul 14.00 siang sampai esok hari pukul 12.00 siang. Data sekunder yaitu terdiri dari data profil perusahaan, data jumlah pengemudi, nama pengemudi. Data primer diperoleh peneliti secara langsung dari objek yang diteliti melalui wawancara menggunakan alat bantu berupa kuesioner. Kuesioner yang digunakan adalah kuesioner kelelahan subjektif dari Industrial Fatique 
Research Committe (IFRC) yang berisi 10 item pertama tentang pelemahan aktivitas, 10 item kedua pelemahan motivasi dan 10 item ketiga mengindikasikan kelelahan fisik atau kelelahan pada bagian tubuh. Pengambilan data dalam penelitian ini yaitu dengan menggunakan alat bantu berupa kuesioner, sedangkan pengukuran berat badan menggunakan alat ukur timbangan dan tinggi badan menggunakan Microtoise Stature Meter. Pengumpulan data dilakukan setelah responden diberi penjelasan sebelum persetujuan dan informed consent. Data dianalisis dengan univariat dan bivariat mengunakan uji Chi-Square

Penelitian ini telah memperoleh persetujuan dari komisi etik penelitian kesehatan masyarakat Universitas Airlangga pada tanggal 19 oktober 2016 dengan No: 541-KEPK.

\section{HASIL}

\section{Gambaran Umum Lokasi Penelitian}

Pool taksi Rungkut Surabaya dipimpin oleh seorang kepala satelit dan didalamnya terdapat beberapa karyawan lain seperti bagian operasional, bagian Penasehat Umum, bagian bengkel dan bagian administrasi. Armada taksi di pool Rungkut ini berjumlah 245 armada dan pengemudi yang berjumlah 310 yang terdiri dari tim siang dan tim malam.

\section{Hubungan Umur Pengemudi Terhadap Tingkat Keluhan Kelelahan Kerja}

Umur pengemudi dikategorikan menjadi dua yaitu umur $<40$ tahun dan $\geq$ 40 tahun. Tabel 1 di atas dapat dilihat bahwa umur pengemudi taksi di Pool Rungkut Surabaya tidak mengalami kelelahan kerja terutama pada umur pengemudi taksi $\geq 40$ tahun. Berdasarkan uji statistik menggunakan Chi-Square didapatkan nilai r sebesar 0,381 menunjukkan bahwa kekuatan hubungan rendah.

\section{Hubungan Masa Kerja Pengemudi Terhadap Tingkat Keluhan Kelelahan Kerja}

Masa kerja pengemudi dikategorikan dibagi menjadi tiga, yaitu $<5$ tahun, 5-10 tahun, $>10$ tahun. Tabel 2 di atas dapat dilihat bahwa pengemudi taksi di pool Rungkut Surabaya tidak mengalami kelelahan terutama yang memiliki masa kerja $>10$ tahun. Hasil uji statistik dengan menggunakan Chi-Square didapatkan nilai r sebesar 2,434 menunjukkan bahwa kekuatan hubungan sangat kuat.

\section{Hubungan Kebiasaan Merokok Pengemudi Terhadap Tingkat Keluhan Kelelahan Kerja}

Kebiasaan merokok pengemudi taksi di Pool Rungkut dikategorikan menjadi dua bagian, yaitu: tidak merokok dan merokok. Tabel 3 di atas dapat dilihat bahwa pengemudi taksi di pool Rungkut Surabaya tidak mengalami kelelahan kerja terutama pada kategori merokok. Hasil uji statistik dengan menggunakan Chi-Square didapatkan nilai $\mathrm{r}$ sebesar 0,008 yang menunjukkan bahwa kekuatan hubungan sangat rendah.

\section{Hubungan Kebiasaan Olahraga Pengemudi Terhadap Tingkat Keluhan Kelelahan Kerja}

Kebiasaan olahraga pengemudi taksi Blue Bird dikategorikan menjadi tiga, yaitu: rutin jika $\geq 3 \times$ dalam seminggu, kadangkadang jika $<3 \times$ dalam seminggu, dan tidak pernah jika dalam seminggu tidak sama sekali. Tabel 4 di atas dapat dilihat bahwa pengemudi taksi di pool Rungkut Surabaya tidak mengalami kelelahan terutama pada kebiasaan olahraga kadang-kadang yaitu jika $<3 \times$ dalam seminggu.

Hasil uji statistik dengan menggunakan Chi-Square didapatkan nilai $\mathrm{r}$ sebesar 1,409 yang menunjukkan bahwa kekuatan hubungan sangat kuat. 
Tabel 1. Hubungan Umur Pengemudi Taksi di Pool Rungkut Surabaya

\begin{tabular}{lccccccc}
\hline \multirow{2}{*}{$\begin{array}{c}\text { Kategori Umur } \\
\text { (Tahun) }\end{array}$} & \multicolumn{4}{c}{ Kelelahan Kerja } & \multicolumn{3}{c}{ Total } \\
\cline { 2 - 6 } & $\mathbf{N}$ & $\mathbf{0}$ & $\mathbf{n}$ & $\mathbf{\%}$ & $\mathbf{n}$ & $\mathbf{\%}$ \\
\hline$<40$ tahun & 16 & 64 & 9 & 36 & 25 & 100 \\
$\geq 40$ Tahun & 19 & 76 & 6 & 24 & 25 & 100 \\
\hline Total & 35 & 70 & 15 & 30 & 50 & 100 \\
\hline
\end{tabular}

Tabel 2. Hubungan Masa Kerja Pengemudi Taksi Di Pool Rungkut Surabaya

\begin{tabular}{|c|c|c|c|c|c|c|}
\hline \multirow{3}{*}{ Kategori Masa Kerja } & \multicolumn{4}{|c|}{ Kelelahan Kerja } & \multirow{2}{*}{\multicolumn{2}{|c|}{ Total }} \\
\hline & \multicolumn{2}{|c|}{ Tidak Lelah } & \multicolumn{2}{|c|}{ Lelah } & & \\
\hline & $\mathbf{n}$ & $\%$ & n & $\%$ & n & $\%$ \\
\hline$<5$ Tahun & 26 & 65 & 14 & 35 & 40 & 100 \\
\hline 5-10 Tahun & 8 & 88,9 & 1 & 11,1 & 9 & 100 \\
\hline$>10$ Tahun & 1 & 100 & 0 & 0 & 1 & 100 \\
\hline Total & 35 & 70 & 15 & 30 & 50 & 100 \\
\hline
\end{tabular}

Tabel 3. Hubungan Kebiasaan Merokok Pengemudi Taksi di Pool Rungkut Surabaya

\begin{tabular}{|c|c|c|c|c|c|c|}
\hline \multirow{3}{*}{ Kategori Kebiasaan Merokok } & \multicolumn{4}{|c|}{ Kelelahan Kerja } & \multirow{2}{*}{\multicolumn{2}{|c|}{ Total }} \\
\hline & \multicolumn{2}{|c|}{ Tidak Lelah } & \multicolumn{2}{|c|}{ Lelah } & & \\
\hline & $\mathbf{n}$ & $\%$ & n & $\%$ & $\mathbf{n}$ & $\%$ \\
\hline Tidak Merokok & 5 & 71,4 & 2 & 28,6 & 7 & 100 \\
\hline Merokok & 30 & 69,8 & 13 & 30,2 & 43 & 100 \\
\hline Total & 35 & 70 & 15 & 30 & 50 & 100 \\
\hline
\end{tabular}

Tabel 4. Hubungan Kebiasaan Olahraga Pengemudi Taksi di Pool Rungkut Surabaya

\begin{tabular}{lccccccc}
\hline \multirow{2}{*}{ Kategori Kebiasaan Olahraga } & \multicolumn{3}{c}{ Kelelahan Kerja } & \multicolumn{3}{c}{ Total } \\
\cline { 2 - 6 } & \multicolumn{2}{c}{ Tidak Lelah } & \multicolumn{2}{c}{ Lelah } & & \\
\cline { 2 - 6 } & $\mathbf{n}$ & $\mathbf{\%}$ & $\mathbf{n}$ & $\mathbf{\%}$ & $\mathbf{n}$ & $\mathbf{\%}$ \\
\hline Rutin & 3 & 75 & 1 & 25 & 4 & 100 \\
Kadang-kadang & 15 & 78,9 & 4 & 21 & 19 & 100 \\
Tidak pernah & 17 & 62,9 & 10 & 37 & 27 & 100 \\
\hline Total & 35 & 70 & 15 & 30 & 50 & 100 \\
\hline
\end{tabular}


Tika Nanda Prastuti, dkk., Analisis Karakteristik Individu dengan Keluhan Kelelahan...

Tabel 5. Hubungan Status Gizi Pengemudi Taksi di Pool Rungkut Surabaya

\begin{tabular}{|c|c|c|c|c|c|c|}
\hline \multirow{3}{*}{ Kategori Status Gizi } & \multicolumn{4}{|c|}{ Kelelahan Kerja } & \multirow{2}{*}{\multicolumn{2}{|c|}{ Total }} \\
\hline & \multicolumn{2}{|c|}{ Tidak Lelah } & \multicolumn{2}{|c|}{ Lelah } & & \\
\hline & $\mathbf{n}$ & $\%$ & $\mathbf{n}$ & $\%$ & $\mathbf{n}$ & $\%$ \\
\hline Kurus & 5 & 83,3 & 1 & 16,7 & 6 & 100 \\
\hline Normal & 18 & 72 & 7 & 28 & 25 & 100 \\
\hline Gemuk & 6 & 66,7 & 3 & 33,3 & 9 & 100 \\
\hline Obesitas & 6 & 60 & 4 & 40 & 10 & 100 \\
\hline Total & 35 & 70 & 15 & 30 & 50 & 100 \\
\hline
\end{tabular}

\section{Hubungan Status Gizi Pengemudi Terhadap Tingkat Keluhan Kelelahan Kerja}

Status gizi pengemudi dikategorikan menjadi empat bagian, yaitu kurus $(17,0-$ $18,4)$, normal $(18,5-25,0)$, gemuk $(25,1-$ $27,0)$, dan obesitas $(>27,0)$. Tabel 5 di atas dapat dilihat bahwa pengemudi taksi di pool Rungkut Surabaya tidak mengalami kelelahan kerja terutama pada kategori status gizi kurus. Hasil uji statistik dengan menggunakan Chi-Square didapatkan nilai r sebesar 1,079 yang menunjukkan bahwa kekuatan hubungan sangat kuat.

\section{PEMBAHASAN}

Faktor umur dapat memengaruhi kekuatan fisik seseorang. Pekerja yang memiliki umur tua kekuatan otot fisiknya dapat berubah (Gilmer, 1996; Shephard, 1988 dalam Maurits, 2010). Umur pengemudi taksi di Pool Rungkut Surabaya menunjukkan bahwa kekuatan hubungan rendah antara umur pengemudi dengan tingkat kelelahan kerja pada pengemudi taksi. Hasil penelitian ini tidak sesuai dengan penelitian yang dilakukan Dinarita dkk (2015), yang mengatakan bahwa umur seseorang berhubungan dengan kelelahan subjektif pada pengemudi mobil trevel. Penelitian ini sejalan dengan penelitian yang dilakukan oleh Ismail (2014), yang mengatakan bahwa tidak terdapat hubungan yang bermakna antara umur dengan kelelahan kerja pada pengemudi truk tangki bahan bakar minya di TBBM PT. Pertamina Kota Makassar.
Penelitian ini sesuai dengan penelitian yang dilakukan Andreani dan Paskarini (2013), yang mengatakan bahwa ada hubungan antara keluhan subjektif dengan umur responden. Faktor yang menyebabkan umur pengemudi taksi tidak berhubungan dengan keluhan kelelahan kerja karena pengemudi yang memiliki umur lebih muda memiliki tingkat emosi yang masih labil, pengalaman bekerja masih rendah dibandingkan dengan pengemudi taksi yang senior, semangat kerjanya kurang. Berbeda dengan pengemudi yang memiliki umur lebih tua yaitu tingkat emosi lebih stabil, memiliki tanggung jawab dan semangat yang tinggi untuk keluarga. (Prastuti, 2017). Menurut Smolensky et al (2001) dalam Kristanto (2013), pengemudi muda ( $<30$ tahun) lebih rentan terhadap rasa kantuk dan mereka lebih sering terlibat dalam kecelakaan kendaraan tunggal ketika kondisi malam dan pagi hari. Menurut Mckernoon (2008) dalam Kristanto (2013), pengemudi yang berusia muda memiliki emosi temperamental sehingga cenderung memiliki masalah dalam berperilaku, memiliki kompetisi dalam kehidupan sosial yang lebih tinggi, dan hubungan interpersonal yang lebih kompleks. Faktor umur merupakan faktor yang sangat penting karena umur berpengaruh terhadap kekuatan fisik dan psikis seseorang. Kekuatan otot pada laki-laki dan wanita mencapai puncaknya pada umur 25-35 tahun dan umur 50-60 tahun kekuatan otot menurun sekitar 15-25\% (Setyawati, 2010). Menurut Chappin dalam Tarwaka dkk (2004), keluhan otot 
skeletal mulai dirasakan pada umur masa kerja 25 tahun. Keluhan yang pertama mulai dirasakan pada usia 35 tahun dan tingkat keluhan tersebut akan semakin bertambah sesuai atau sejalan dengan bertambahnya usia.

Masa kerja adalah aktivitas kerja seseorang yang diukur dalam satuan waktu tertentu. Apabila aktivitas atau kegiatan tersebut dilakukan secara terus-menerus atau bertahun-tahun dapat mengakibatkan gangguan pada tubuh. Tekanan fisik pada suatu kurun waktu tertentu akan mengakibatkan berkurangnya atau menurunnya kinerja otot seperti gejala makin menurunnya gerakan. Tekanan secara fisik dan psikis yang dialami seseorang setiap hari mengakibatkan memburuknya kesehatan atau disebut juga dengan kelelahan klinis atau kronis (Budiono dkk, 2008). Masa kerja erat hubungannya dengan kemampuan adaptasi antara seorang pekerja dengan pekerjaan dan lingkungan kerja. Proses adaptasi dapat memberikan efek positif seperti dapat menurunkan ketegangan dan peningkatan aktivitas atau performa saat kerja. Efek negatifnya jika batas ketahanan tubuh yang berlebihan akibat tekanan yang diperoleh pada saat proses kerja. Hal ini menjadi sebab timbulnya kelelahan pada penurunan fungsi psikologi dan fisiologi (Marif, 2013). Masa kerja yang lama akan mengakibatkan perasaan jenuh dan bosan apabila pekerjaan yang dilakukan tersebut monoton. Lamanya masa kerja ditentukan oleh tingkat kelelahan dan keluhan otot yang dirasakan oleh pekerja. Apabila semakin lama seseorang bekerja maka akan semakin lama pula melakukan kegiatan yang berulang-ulang. Hal ini dapat meningkatkan risiko kelelahan dan keluhan musculoskeletal (Tarwaka, 2004) Masa kerja pengemudi taksi di Pool Rungkut Surabaya menunjukkan bahwa memiliki kekuatan hubungan sangat kuat antara masa kerja dengan kelelahan kerja pada pengemudi taksi. Penelitian ini tidak sesuai atau tidak sejalan dengan penelitian yang dilakukan Eraliesa (2009), yang mengatakan bahwa ada hubungan bermakna antara variabel masa kerja dengan kelelahan kerja. Semakin lama seseorang bekerja pada suatu pekerjaan, maka beban kerja yang dirasakan akan semakin kecil karena telah terbiasa (Suma'mur 2011). Menurut Setyawati (2010), tidak adanya hubungan antara masa kerja dengan kelelahan kerja dikarenakan keadaan tersebut diimbangi oleh pengalaman yang ada maupun kematangan mental pekerja tersebut. Masa kerja yang lama dapat berdampak pada timbulnya kelelahan. Pekerjaan yang dilakukan secara terus-menerus dapat berpengaruh terhadap sistem peredaran darah, sistem pencernaan, otot, syaraf dan sistem pernafasan (Suma'mur, 1999). Masa kerja mempunyai pengaruh positif di mana semakin lama seseorang bekerja, akan semakin berpengalaman dalam melakukan pekerjaan. Masa kerja berdampak negatif karena dapat menimbulkan rasa kebosanan atau menjemukan dan kelelahan kerja (Budiono, 2008). Faktor yang menyebabkan masa kerja pengemudi tidak berhubungan dikarenakan masa kerja pengemudi $<5$ tahun pengalaman saat bekerja mencari penumpang kurang sehingga waktu kerja banyak digunakan untuk menunggu penumpang yang datang dan waktu istirahat pengemudi yang lebih banyak dari pada mencari penumpang berkeliling di jalan.

Di dalam sebatang rokok terdapat 4000 jenis senyawa kimia. Ada tiga komponen utama dalam rokok yaitu nikotin, tar dan karbon monoksida (CO). Tar merupakan zat yang berbahaya yang bisa menyebabkan kanker. Karbon Monoksida merupakan gas beracun yang dapat menurunkan kandungan $\mathrm{O}_{2}$ di dalam darah (Kemenkes RI, 2012). Nikotin dapat membuat kecanduan karena dapat memicu dopamine. Dopamine merupakan unsur kimia di dalam otak yang berkaitan dengan perasaan senang. Nikotin bersifat adiktif sehingga rokok dapat membahayakan bagi kesehatan tubuh (Aksoro dan Aksoro, 2009). Kebiasaan merokok pengemudi taksi di Pool Rungkut Surabaya menunjukkan kekuatan hubungan 
sangat lemah antara kebiasaan merokok dengan kelelahan kerja pada pengemudi taksi. Penelitian ini tidak sesuai atau tidak sejalan dengan penelitian yang dilakukan oleh Andreani dan Paskarini (2014), yang mengatakan bahwa ada hubungan antara kebiasaan merokok dengan keluhan subjektif. Menurut Setiawaty (2008), merokok dapat mengakibatkan perubahan struktur dan fungsi saluran pernapasan serta jaringan paru-paru. Mayoritas seseorang yang mempunyai kebiasaan merokok dan frekuensi merokok yang tinggi cenderung mengalami kelelahan kerja. Semakin lama dan tinggi frekuensi merokok, keluhan otot yang dirasakan akan semakin tinggi. Hal ini berhubungan kuat dengan kondisi kesegaran jasmani seseorang dan kandungan zat-zat dalam asap rokok yang berbahaya dapat memicu tingginya keluhan otot saat bekerja. Seseorang yang mengonsumsi rokok satu pak atau lebih dalam satu hari dapat menurunkan denyut jantung dua atau tiga denyutan tiap menit (Hanson., dkk, 1983 dalam Marif, 2013). Dalam laporan resmi World Health Organization (WHO), jumlah kematian akibat merokok tiap tahun adalah 4,9 juta orang per tahunnya. Penelitian ini menunjukkan adanya hubungan kebiasaan merokok dengan keluhan kelelahan kerja, terutama untuk pekerjaan yang memerlukan pengerahan otot, karena nikotin pada rokok dapat menyebabkan berkurangnya aliran darah ke jaringan. Selain itu, merokok juga dapat menyebabkan berkurangnya kandungan mineral pada tulang sehingga menyebabkan nyeri akibat terjadinya keretakan atau kerusakan pada tulang (Kantana, 2010).

Menurut penelitian yang dilakukan oleh Fitrianingsih dan Hariyono (2011), faktor yang dapat menyebabkan terjadinya nyeri punggung adalah kebiasaan merokok yang dapat berpengaruh terhadap meningkatnya keluhan otot. Meningkatnya keluhan otot erat hubungannya dengan lama dan tingkat kebiasaan merokok. Pengemudi taksi di Pool Rungkut Surabaya sebagian besar merokok, penyebab pekerja mengonsumsi rokok karena dengan merokok pekerja akan merasa lebih percaya diri atau bergairah, lebih berkonsentrasi saat bekerja dan dapat mengurangi rasa lelah, stress dan bosan sehingga mengonsumsi rokok menjadi suatu kebiasaan yang dilakukan pengemudi.

Kebugaran jasmani adalah kemampuan tubuh seseorang dalam melakukan pekerjaan atau kegiatan sehari-hari tanpa menimbulkan kelelahan yang berarti, sedangkan olahraga merupakan bentuk aktivitas fisik yang terencana, terstruktur, dan berkesinambungan serta melibatkan gerakan tubuh berulangulang dengan aturan tertentu yang bertujuan untuk meningkatkan kebugaran jasmani (Kementerian Kesehatan RI, 2015). Menurut Hairy (1989) dan Hopkins (2002) dalam Sedarmayanti (2011), mengatakan bahwa kesegaran jasmani adalah kemampuan tubuh manusia untuk dapat melakukan penyesuaian terhadap beban fisik yang sedang dihadapi tetapi tanpa menimbulkan kelelahan yang berarti dan sebagai kapasitas cadangan untuk melakukan aktivitas selanjutnya. Pada penelitian ini kebiasaan olahraga pengemudi taksi di Pool Rungkut Surabaya menunjukkan kekuatan hubungan sangat kuat antara kebiasaan olahraga dengan kelelahan kerja pengemudi taksi. Penelitian ini tidak sejalan atau tidak sesuai dengan penelitian yang dilakukan oleh Andreani dan Paskarini (2013), yang mengatakan bahwa ada hubungan antara keluhan subjektif dengan frekuensi kebiasaan olahraga.

Keluhan nyeri otot ini jarang sekali ditemukan pada seseorang yang dalam aktivitas kesehariannya memiliki waktu cukup untuk beristirahat, sedangkan bagi seseorang yang dalam aktivitas setiap harinya melakukan pekerjaan yang memerlukan pengarahan atau tenaga besar dan tidak mempunyai waktu istirahat cukup dapat dipastikan akan mengalami keluhan otot. Tingkat keluhan otot ini juga sangat berpengaruh pada tingkat kesegaran tubuh (Tarwaka, 2010). Faktor-faktor yang menyebabkan tidak adanya hubungan kelelahan kerja pada pengemudi taksi di pool 
Rungkut Surabaya karena banyak pengemudi yang tidak sempat meluangkan waktunya untuk berolahraga dan ada beberapa yang malas untuk melakukan olahraga (Prastuti, 2017). Tingkat kesegaran tubuh yang rendah akan berdampak pada tingginya risiko terjadi penyakit keluhan otot. Keluhan otot tersebut akan meningkat sejalan dengan bertambahnya aktivitas fisik (Tarwaka, 2010). Menurut Tarwaka dkk (2004), olahraga berhubungan dengan kebugaran jasmani seseorang. Seseorang yang terbiasa berolahraga akan memiliki kebugaran jasmani yang lebih baik dibandingkan seseorang yang tidak terbiasa melakukan olahraga. Seseorang yang memiliki kebugaran jasmani baik maka tidak akan mudah mengalami kelelahan saat bekerja. Sebaliknya pekerja mudah mengalami kelelahan apabila kebugaran jasmaninya kurang baik (Tarwaka dkk, 2004).

Kusmana dalam Nur (2011), mengatakan bahwa olahraga teratur dapat mencegah kegemukan dan dampak negatif lainnya, dapat menguatkan fisik dan lebih mengefisienkan kinerja otot-otot tubuh, seperti otot pernafasan, otot jantung dan otototot rangka tubuh, dan lebih melancarkan peredaran darah ke dalam sel-sel tubuh dan pembuangan bahan-bahan sisa dari sel tubuh menjadi lebih baik. Bila kurang berolahraga maka terjadi kelemahan pada otot dan dapat kehilangan kelenturan, namun jika olahraga dikerjakan secara teratur dan sesuai dengan anjuran dapat meningkatkan kesegaran jasmani yang akhirnya akan meningkatkan ketahanan fisik (Soeparman, 2001, Moeloek, 1998 dalam Viyaya dan Tanya, 2008).

Status gizi merupakan salah satu bagian penting dari kesehatan seseorang. Status gizi menunjukkan suatu keadaan diri yang diakibatkan oleh konsumsi, penyerapan dan penggunaan zat gizi dari makanan dalam jangka waktu yang lama. Salah satu indeks antropometri yang sering digunakan untuk menilai status gizi adalah Indeks Massa Tubuh (IMT). Indeks Masa Tubuh merupakan alat yang digunakan untuk memantau status gizi orang dewasa. Penggunaan Indeks Masa Tubuh berlaku untuk orang dewasa berumur di atas 18 tahun (Supariasa dkk, 2002).

Status gizi pengemudi taksi di Pool Rungkut Surabaya menunjukkan kekuatan hubungan sangat kuat antara status gizi dengan keluhan kelelahan kerja pada pengemudi taksi. Penelitian ini sesuai atau sejalan dengan penelitian yang dilakukan oleh Kristanto (2013), yang mengatakan tidak terdapat hubungan yang bermakna antara Indeks Masa Tubuh (IMT) dengan kelelahan. Penelitian ini tidak sejalan atau tidak sesuai dengan penelitian yang dilakukan Syahlefi dkk (2012), yang mengatakan terdapat hubungan antara status gizi/Indeks Masa Tubuh dengan kejadian kelelahan pada pengemudi bus CV. Makmur Jurusan MedanPekan Baru. Indeks Masa Tubuh yang tidak normal dapat memengaruhi beban kerja bagi tenaga kerja.

Pengemudi yang gemuk atau terlalu kurus akan berdampak bagi kondisi fisik pada saat bekerja. Pengemudi tidak bisa bekerja dengan lincah karena saat bekerja merasa terganggu oleh berat badan tubuhnya. Orang yang memiliki tubuh besar jika banyak gerak lebih cepat lelah dan kinerjanya menurun. Faktor-faktor yang dapat memengaruhi kebutuhan gizi seseorang yaitu ukuran tubuh. Semakin besar ukuran tubuh seseorang maka semakin besar kebutuhan kalori. Jika gizi seimbang maka kesehatan tenaga kerja dapat dipertahankan dan tenaga kerja akan dapat bekerja dengan baik, tidak mudah lelah atau capek dan mengurangi terjadinya tingkat kesalahan (Tarwaka dkk, 2004).

Seseorang yang gemuk umumnya memerlukan energi yang lebih besar untuk melakukan aktivitasnya dibandingkan orang yang memiliki status gizi baik. Aktivitas yang sama, seseorang dengan status gizi lebih akan mengeluarkan energi yang lebih besar daripada seseorang dengan status gizi baik. Status gizi berlebihan juga dapat berdampak pada penurunan fungsi tubuh seperti otot, paru dan organ tubuh lainnya yang akan membuat tubuh bekerja lebih keras untuk 
dapat mengimbanginya sehingga tubuh menjadi cepat lelah (Sedarmayanti,2011).

\section{SIMPULAN}

Berdasarkan hasil penelitian yang telah dilakukan pada pengemudi taksi di pool Rungkut Surabaya dapat ditarik kesimpulan bahwa: umur pengemudi taksi memiliki kekuatan hubungan rendah, masa kerja pengemudi taksi memiliki kekuatan hubungan sangat kuat, kebiasaan merokok pengemudi taksi memiliki kekuatan hubungan sangat rendah, kebiasaan olahraga memiliki kekuatan sangat kuat dan status gizi pengemudi taksi memiliki kekuatan sangat kuat dengan keluhan kelelahan kerja pada pengemudi taksi di pool Rungkut Surabaya.

\section{DAFTAR PUSTAKA}

Aksoro, B., Aksoro,G. 2009. Bebas Kelelahan. Yogyakarta: Kanisius.

Budiono,A.M.S. 2008. Bunga Rampai Higiene Perusahaan Ergonomi (HIPERKES) dan Kesehatan dan Keselamatan Kerja. Badan Penerbit Universitas Diponegoro, Semarang.

Andreani, M,U,D., Paskarini, I. 2013. Sikap Kerja yang Berhubungan dengan Keluhan Subjektif Pada Penjahit Di Jalan Patua Surabaya. Jurnal Promkes. Vol. 1, No. 2: 201-208.

Budiono, AMS., Jusuf, RMS., dan Pusparini, A. 2008. Hiperkes \& KK. Semarang: Badan Penerbit Universitas Diponegoro Semarang.

Dewan Perwakilan Rakyat Daerah (DPRD) Provisi Jawa Timur. 2013. Angka Kecelakaan Lalu Lintas di Jatim Semakin Tinggi. http://dprd.jatimprov.go.id/berita/ id/51/angka-kecelakaan-lalu-lintasdi-jatim-semakin-tinggi- (sanitasi 20 Desember 2016)

Dinarita, I., Akhmad., Galib, D. 2015. Hubungan Faktor Individu dengan Tingkat Kelelahan Kerja Subjektif Pada Supir Travel Kangoroo Premier di Kota
Samarinda. Jurnal Kesmas. Vol. 01, No. 04, Hal 18-22.

Eraliesa, F. 2009. Hubungan Faktor Individu dengan Kelelahan Kerja Pada Tenaga Kerja Bongkar Muat di Pelabuhan Tapaktuan Kecamatan Tapaktuan Aceh Selatan Tahun 2008. Skripsi. Universitas Sumatra Utara.

Fahmi, R. 2015. Gambaran Kelelahan dan Keluhan Muskuloskeletal Pada Pengemudi Bus Malam Jarak Jauh PO. Restu Mulya. The Indonesian Journal of Occupational Safety and Health. Universitas Airlangga. Vol. 4, No. 2: 167-176.

Fitrianingsih., Hariyono, W. 2011. Hubungan Umur, Beban Kerja dan Posisi Duduk Saat Bekerja dengan Keluhan Nyeri Pungggung Pada Pengemudi Angkutan Kota di Kabupaten Wonosobo Jawa Tengah. Jurnal Kesmas Ahmad Dahlan. Vol. 5, No. 2: 162-232.

Ismail. 2014. Faktor yang Berhubungan dengan Kelelahan Kerja Pada Pengemudi Truk Tangki Bahan Bakar Minyak di TBBM PT. Pertamina (PERSERO) Kota Makassar Tahun 2014. Skripsi. Makassar: Fakultas Kesehatan Masyarakat Universitas Hasanuddin.

Kantana, T. 2010. Faktor-faktor yang Memengaruhi Keluhan Low Back Pain Kegiatan Mengemudi Tim Ekspedisi PT. Enseval Putera Mega Trading Jakarta Tahun 2010. Skripsi. Jakarta. Universitas Islam Negeri Syarif Hidayatullah.

Kementerian Kesehatan RI. 2015. Pembinaan Kesehatan Olahraga Di Indonesia. Jakarta: Pusat Data dan Informasi Kementerian Kesehatan RI.

Kementerian Kesehatan RI, 2012. Penyakit Tidak Menular. Jakarta: Direktorat PPTM, P2PL Kemenkes RI.

Kementerian Perhubungan Republik Indonesia. 2015. Target Penurunan Tingkat Kecelakaan. Dephub.go.id/ berita/baca/targetpenurunan-tingkatkecelakaan-hingga-50 persen-pada-tahun 2019/?cat=QmVyaXRhfHNIY3Rpb24tN $\mathrm{jU}=$ (sanitasi 26 maret 2016) 
Kepolisian Negara RI. 2015. Surabaya Kota Macet Terburuk Keempat Di Dunia http:// halopolisi.com/2015/02/04/surabayakota-macet-terburuk-keempat-di-dunia satlantas-polrestabes-surabaya-siapkanantisipasi/(sanitasi 9 April 2016)

Kristanto, A. 2013. Kajian Faktor-Faktor Risiko yang Berhubungan dengan Kelelahan Pengemudi Truk Trailer Di PT AMI Tahun 2012. Tesis. Universitas Indonesia.

Marif, A. 2013. Faktor-faktor yang Berhubungan dengan Kelelahan Pada Pekerja Pembuatan Pipa dan Menra Tambat Lepas Pantai (EPC3) di Proyek Banyu Urip PT. Rekayasa Industri, SerangBanten Tahun 2013. Skripsi. Universitas Islam Negeri Syarif Hidayatullah Jakarta, Jakarta.

Maurits, L.S. 2010. Selintas tentang Kelelahan Kerja. Yogyakarta: Amara Books.

Nur, H. 2011. Faktor-faktoryang Berhubungan dengan Muskuloskeletal Disorders (MSDs) pada Pekerja Furniture di Kecamatan Benda Kota Tangerang Tahun 2011. Skripsi. UIN Syarif Hidayatullah.

Prastuti, T,N. 2016. Hubungan Karakteristik Individu dan Jarak Tempuh dengan Keluhan Kelelahan Kerja Pada Pengemudi Taksi. Skripsi. Universitas Airlangga.

Sedarmayanti. 2011. Tata Kerja dan Produktivitas Kerja. Bandung: CV. Mandar Maju.

Setyawati, L. 2010. Selintas tentang Kelelahan Kerja. Yogyakarta: Amara Books.

Setiawaty. 2008. Kelelahan Kerja Kronis, Kajian terhadap Kelelahan Kerja, Penyusunan Alat Ukur serta Hubungannya dengan Waktu Reaksi dan Produktivitas Kerja. Disertasi. Yogyakarta: Universitas Gadjah Mada.

Suma'mur, P.K. 1999. Ergonomi untuk Produktivitas Kerja. Jakarta: CV Haji Masagung.
Suma'mur, P.K. 2009. Higiene Perusahaan dan Kesehatan Kerja (Hiperkes). Jakarta: Sagung Seto.

Suma'mur, P.K. 2011. Higiene Perusahaan dan Kesehatan Kerja (HIPERKES) Edisi 2. Jakarta: CV Sagung Seto.

Supariasa, I.D.N., Bakri, B., Fajar, I. 2002. Penilaian Status Gizi. Jakarta: EGC.

Syahlefi, M.R. 2014. Faktor-faktor yang Berhubungan dengan Kelelahan Pengemudi Bus di CV. Makmur Medan Tahun 2014. Skripsi Universitas Sumatera Utara.

Tarwaka., Solikhul, H.A., Bakri, S.L. 2004. Ergonomi untuk Kesehatan, Keselamatan Kerja, dan Produktivitas. Surakarta: Uniba Press.

Tarwaka. 2010. Ergonomi Industri. Solo: Harapan Press Solo.

Umyati, A., Yadi, Y,H., Sandi, E.S,N. 2015. Pengukuran Kelelahan Kerja Pengemudi Bis dengan Aspek Fisiologis Kerja dan Metode Industrial Fatique Research Committee (IFRC). Skripsi. Banten; Universitas Sultan Ageng Tirtayasa.

Undang-undang Republik Indonesia No. 22 Tahun 2009 tentang Lalu Lintas dan Angkutan Jalan.

Viyaya, S., Tanya, E. 2008. Beberapa Faktor yang berhubungan dengan Keluhan Nyeri Pinggang Pada Perawat Rawat Inap. Tesis. Universitas Airlangga. Surabaya.

WHO. 2013. Status Keselamatan Jalan di WHO Regional Asia Tengara Tahun 2013.http://www.searo.who.int/entity/ disabilities_injury_rehabilitation/ documents/roadsafety-factsheetino.pdf (sanitasi 20 Desember 2016)

Yogisutanti, G., Kusnanto, H., Setyawati, L., Otsuka, Y. 2013. Kebiasaan Makan Pagi, Lama Tidur dan Kelelahan Kerja (Fatigue) Pada Dosen. Jurnal Kesehatan Masyarakat. 9 (1) (2013) 53-57. 